\title{
The Impact of Index Future Introduction on Spot Market Returns and Trading Volume: Evidence from Ho Chi Minh Stock Exchange
}

\author{
Anh Thi Kim NGUYEN ${ }^{1}$, Loc Dong TRUONG ${ }^{2}$
}

Received: June 02, 2020 Revised: June 28, 2020 Accepted: July 09, 2020

\begin{abstract}
The objective of this study is to enrich the literature by investigating the impact of introduction of index future trading on spot market returns and trading volume in Vietnam. Data used in this study mainly consist of daily VN30-Index and market trading volume series during the period from February $6^{\text {th }}, 2012$ to December $31^{\text {st }}, 2019$. Using OLS, GARCH $(1,1)$ and EGARCH $(1,1)$ models, the empirical findings consistently confirm that the introduction of index future trading has no impact on the spot market returns. In addition, the results of the EGARCH(1,1) model indicate that the leverage effect on the spot market volatility is existence in HOSE. Specifically, bad news has a greater effect on the market volatility than good news of the same size. Moreover, our empirical findings reveal that the introduction of index future contracts has the positive impact on the underlying market trading volume. Specifically, the trading volume of the post-index futures introduction increases by 7.5 percent compared with the pre-index futures introduction. Finally, the results obtained from the Granger causality test for the relationship between the spot market returns and the future trading activity confirm that only uni-directional causality running from the market returns to the future trading activity exists in HOSE.
\end{abstract}

Keywords: Index Future Trading, Spot Market Returns, Spot Market Trading Volume, Vietnam

JEL Classification Code: G10, G12, G13

\section{Introduction}

Derivative markets have played an important role in the development of stock markets in each country. Therefore, the impact of derivatives trading on the spot market has received a remarkable attention of financial economists and policy makers for the last decades. Most of studies in this field have focused on the impact of derivatives trading on the volatility of underlying stocks. Many studies claim that the introduction of derivatives trading is associated with the increase in volatility of the spot market (Lee \& Ohm, 1992; Antoniou \& Holmes, 1995; Gulen \& Mayhew, 2000;

${ }^{1}$ First Author. Lecturer, Falculty of Economics and Business Administration, An Giang University, Vietnam National University Ho Chi Minh City, Vietnam. Email: ntkanh@agu.edu.vn

${ }^{2}$ Corresponding Author. Associate Professor, College of Economics,

Can Tho University, Vietnam [Postal Address: Campus II, 3/2

Street, Ninh Kieu District, Can Tho City, 900000, Viet Nam] Email: tdloc@ctu.edu.vn

(c) Copyright: The Author(s)

This is an Open Access article distributed under the terms of the Creative Commons Attribution Non-Commercial License (http://Creativecommons.org/licenses/by-nc/4.0/) which permits unrestricted noncommercial use, distribution, and reproduction in any medium, provided the original work is properly cited.
Yu, 2001; Bae, Kwon, \& Park, 2004; Pok \& Poshakwale, 2004). Theoretically, the higher volatility (higher risk) is required the higher rate of return on the stocks. In other words, the introduction of derivatives trading could result in higher returns of the underlying stocks. The positive effects of derivatives trading on returns of the underlying stocks have been documented for some developed stock markets (Detemple \& Jorion, 1990; Watt, Yadav, \& Draper, 1992). Furthermore, it can be argued that the introduction of derivative trading can lead to the increase in trading volume of underlying stocks because the introduction of derivative trading can attract more investors to participate in the spot markets. Lee and Tong (1998), Pilar and Rafael (2012), and Robbani and Bhuyan (2004) report evidences that support for this argument. However, Yilgor and Mebounou (2016) do not find any significant impact of the derivatives trading on the spot market trading volume in Turkey.

Ho Chi Minh Stock Exchange (HOSE), formerly named as the Securities Trading Centre and the first stock exchange in Vietnam, was launched on July 28th 2000. By the end of 2019, a total of 378 joint-stock companies with a total market capitalization of VND 3,279,611 billion (USD 139.68 billion) have been listed on the Exchange. The Vietnam 
derivatives market has been established since August 10th, 2017. The first product has been traded in the market is the VN30-index future contract. Although the product traded in the market is limited, the market has well performed so far in terms of trading volume and the number of investors. According to the statistics from the Ha Noi Stock Exchange, the futures trading volume in 2019 reached an average of 88,186 contracts per trading session. In addition, the open interests and number of derivatives trading accounts were 5,567,121 contracts and 92,202 accounts by the end of 2019, respectively. It is observed that the introduction and development of the derivative market could have significantly impacted on the spot market. However, to the best of our knowledge, no study has been conducted on this issue for the HOSE.

The aim of this paper is to investigate the impact of index future introduction on spot market returns and trading volume of HOSE. The contribution of this paper is to enrich the literature by providing the first empirical evidences on this field for the case of HOSE. The HOSE is the interesting case for studying because it is one of a few frontier stock markets in developing countries that have concurrently implemented the derivatives trading and the derivatives market is in the starting period. The remainder of the paper is structured as follows. Section 2 presents the empirical literature. Section 3 provides an overview of HOSE and index futures contract in Vietnam while Section 4 details the data that are used in this study and the research methodology. Section 5 discusses the empirical results. Finally, conclusions are presented in Section 6.

\section{Literature Review}

The impact of derivatives trading on underlying stock markets have been extensively studied and documented in the financial literature for the last decades. Numerous studies have been done focusing on the impact of future trading on the return volatility of underlying stocks. However, findings from these studies have not been consistent in the literature. Some studies claim that the introduction of futures trading reduce the volatility of spot markets (McKenzie, Brailsford, \& Faff, 2001; Bologna \& Cavallo, 2002; Pilar \& Rafael, 2002; Tripathy, Ramana Rao, \& Kanagaraj, 2009; Hou \& Li, 2014; Yilgor \& Mebounou, 2016). The stabilization impact of futures trading can be explained by two main reasons: (1) future trading provides positive feedback trading in spot market; and (2) future trading leads to the increase in liquidity of the spot market. On the contrary, some other studies document that the introduction of futures trading leads to the increase in the spot market volatility (Lee \& Ohk, 1992; Antoniou \& Holmes, 1995; Gulen \& Mayhew, 2000; Yu, 2001; Bae, Kwon, \& Park, 2004; Pok \& Poshakwale, 2004). The increase in the volatility of the spot market after the introduction of the futures contracts can be explained as a result of high degree of leverage and the participation of speculative traders in the futures markets. Moreover, Park and Park (2020) investigate the impact of hedging with derivatives on firm-level crash risk in Korea. The results derived from this study indicate that hedging with derivatives leads to greater possibility of future crash risk.

In addition, some evidences of the impact of derivatives trading on returns of underlying stocks have also been found in the literature. Detemple and Jorion (1990) investigate the impact of option introductions on the underlying stocks in the US for the period 1973-1986. They find the price increase of underlying stocks following the new options listing. Similarly, Watt, Yadav and Draper (1992) measure the impact of option listing on returns of underlying stocks in the UK. The authors claim that option listing results in a temporary price increase. In addition, Aitkena and Segara (2005) investigate the impact of warrants introduction on the price of underlying stocks listed on the Australian Stock Exchange. The main finding derived from the study shows the significant negative abnormal returns of the underlying stocks on both the announcement and listing date of derivative warrants. In other respects, Faff and McKenzie (2002) investigate the impact of index futures introduction on the seasonal daily returns of the spot index for seven developed stock markets. This study documents that the introduction of index futures results in reducing seasonality of daily mean returns of the underlying indexes.

Regarding the impact of derivatives trading on stocks trading volume, some studies assert that trading volume of underlying stocks significantly increases after the introduction of the derivatives trading. Specifically, Lee and Tong (1998) examine the effects of stock future introduction on trading volume of the underlying stocks in Australia. Findings from this study confirm that trading volume of the underlying stocks significantly increases after the introduction of stock future trading. Similarly, Pilar and Rafael (2012) claim that the introduction of futures and options trading in the Spanish stock market leads to the significant increase in the market trading volume. Moreover, Robbani and Bhuyan (2004) claim that the introduction of futures and options on the Dow Jones Industrial Average is associated with the increase in the market trading volume. Aitkena and Segara (2005) measure the impact of warrants introduction on trading volume of underlying stocks listed on the Australian Stock Exchange. The findings of this study show that trading volume of underlying stocks is significantly higher in the post-warrant listing period. On the contrary, Yilgor and Mebounou (2016) do not find any significant effects of the derivatives trading on the volume of the Turkish spot market.

In short, the impact of derivative trading on underlying stock markets has widely documented in the literature. Empirical evidences regarding the impact of derivative 
trading on the volatility of underlying stocks have not been consistent. Some studies assert that the introduction of derivatives trading lead to the decrease in the spot market volatility while others studies claim that the derivatives trading is associated with the increase in the underlying market volatility. Moreover, the positive impact of derivatives trading on returns and trading volume of underlying stocks has also been found in the literature.

\section{Overview of the HOSE and Index Future Contract in Vietnam}

The HOSE, formerly named as the Securities Trading Centre, was launched on July 28th 2000. At the opening trading session, only two individual stocks with a total market capitalisation of VND 444,000 million (about USD 18.74 million) were traded on the market. The growth of the number of listed companies has been rather slow in the beginning stage. At the end of 2001 still only 10 joint-stock companies were listed. However, the number of listed companies has remarkably increased in the last few years. By the end of 2019, a total of 378 joint-stock companies with a total market capitalization of VND 3,279,611 billion (USD 139.68 billion) have been given permission to float their shares on the Exchange. Most of the listed firms are former stateowned enterprises (SOEs) that were previously restructured by equitization, the Vietnamese version of privatization (e.g., Truong, Lanjouw, \& Lensink, 2006).

All shares listed at the HOSE should be denominated in Vietnamese Dong (VND) with a standardized par value for each of VND 10,000. For the first period from July 28, 2000 to March 12002 , trading sessions have been conducted on Monday, Wednesday and Friday. From March 1, 2002, the market trades daily with two order-matching sessions at $9.20 \mathrm{am}$ and $10.30 \mathrm{am}$. To satisfy the requirements for the market's growth, the HOSE has applied continuous order matching method since July $30^{\text {th }}, 2007$. Some key indicators of the HOSE during the period from 2012 to 2019 are presented in Table 1.
The VN-Index, the official market price index of the HOSE, is a composite index calculated from prices of all common stocks traded on the HOSE. Specifically, it is a market capitalization weighted price index which compares the current market value of all listed common shares to the value on the base date of July $28^{\text {th }}, 2000$ when the first session was traded on the market and it was primarily set at 100 points. The calculation of VN-Index is based on market capitalization and ignores the free-float shares. By this way, the Index can be distorted. With the aim to address the limitations of the VN-Index, the VN-30 Index has been introduced since February $6^{\text {th }}, 2012$. The VN30-Index is a market capitalization weighted index which is adjusted by free-float shares ratio (liquidity) of 30 large capitalization and high liquidity stocks listed on the HOSE.

Like other markets, the Vietnam derivatives market started trading on index future contracts and the underlying asset is the VN30-Index. Specifically, the VN30-Index future contract was officially launched on August $10^{\text {th }}, 2017$. There are some reasons to choose the VN30-Index future contract as the first product in the Vietnam derivative market. First of all, this kind of derivative is simple in trading and pricing methods. In addition, the index future contract based on the VN30-Index is less risky than individual stocks future.

At a certain time, four different kinds of index future contracts with different maturity months are traded in the market. Maturity months of the VN30-Index future contracts are current month, the next month and the last month of the next two quarters. By regulation, investors need to post a certain amount of cash, known as the initial margin requirement and additional margin when necessary based on the results of their trading. The initial margin rate that is set by the Securities Depository Center is currently 10 percent. Some characteristics of VN30-Index futures contract are presented in Table 2.

Over 2 years since being established, the Vietnam derivative market has achieved impressive results in trading volume as well as number of investors. Specifically, at the end of 2019, the average daily trading volume and open

Table 1: Key indicators for the HOSE over the period of 2012-2019

\begin{tabular}{|l|c|c|c|c|c|c|c|c|}
\hline \multicolumn{1}{|c|}{ Indicators } & $\mathbf{2 0 1 2}$ & $\mathbf{2 0 1 3}$ & $\mathbf{2 0 1 4}$ & $\mathbf{2 0 1 5}$ & $\mathbf{2 0 1 6}$ & $\mathbf{2 0 1 7}$ & $\mathbf{2 0 1 8}$ & $\mathbf{2 0 1 9}$ \\
\hline No. of listed companies & 308 & 301 & 305 & 307 & 320 & 344 & 373 & 378 \\
\hline Market capitalization (bil. USD) & 32.6 & 35.9 & 42.0 & 48.8 & 63.5 & 111.3 & 122.5 & 139.7 \\
\hline Market capitalization on GDP (\%) & 24.0 & 23.5 & 24.7 & 27.3 & 35.0 & 57.0 & 52.0 & 60.0 \\
\hline Average daily trading value (mil. USD) & 35.8 & 45.3 & 92.5 & 83.7 & 104.0 & 178.9 & 237.4 & 173.8 \\
\hline VN30-Index & 485.4 & 562.2 & 601.7 & 595.6 & 628.2 & 975.5 & 855.0 & 897.1 \\
\hline
\end{tabular}

Source: Annual reports of the HOSE

Note: All figures are collected at the end of each year. 
Table 2: Characteristics of the VN30-Index future contract

\begin{tabular}{|l|l|}
\hline \multicolumn{1}{|c|}{ Characteristics } & \multicolumn{1}{c|}{ Regulations } \\
\hline Contract size & VND $100.000 *$ VN30-Index \\
\hline Trading methods & Order-matching and put-through \\
\hline Trading unit & 1 contract \\
\hline Order limits & 500 contracts/order \\
\hline Initial margin rate & $10 \%$ \\
\hline Reference price & The settlement price at the end of the previous trading day \\
\hline Price limits & $+/-7 \%$ \\
\hline Final trading day for each kind of contract & $\begin{array}{l}\text { The } 3^{\text {rd }} \text { Thursday in the contract month. If that day is a non-trading day, final } \\
\text { trading day will be adjusted to the previous trading day. }\end{array}$ \\
\hline
\end{tabular}

interest stood at 88,186 contracts and 5,567,121 contracts, respectively. The trading volume of foreign investors has been continuously increasing, but the proportion of foreign investor trading volume to total market trading volume has been low, accounting for less than $1 \%$. Along with achievements in the market trading volume, the number of derivative trading accounts has been continuously increasing during the period from 2017 to 2019. Another important characteristic of the Vietnam derivatives market is that the individual investors are dominated in the market. It can be the factor that makes the market more volatility. Some selected indicators of the Vietnam derivatives market over the beginning stage of operation are presented in Table 3.

\section{Data and Methodology}

\subsection{Data}

The data used in this study are the daily VN30-Index, underlying market trading volume, trading volume of future contracts and open interests over the period from February $6^{\text {th }}, 2012$ (when the VN30-Index was officially launched in the HOSE) to December, $31^{\text {st }}$ 2019. Based on the collected market index, market returns are computed as follows:

$$
R_{t}=\log \left(I_{t}\right)-\log \left(I_{t-1}\right)=\log \left(I_{t} / I_{t-1}\right)
$$

where,

$R t$ : market returns at day t;

It: VN30-Index at day $t$;

It-1: VN30-Index at day $t-1$.

\subsection{Methodology}

To test for the impact of index futures introduction on spot market returns (VN30-Index), a set of regression models are employed in this study. The first model, which is used to examine the index futures trading impact, is the OLS (Ordinary Least Square) regression with the following form:

$$
\begin{aligned}
R_{t} & =\alpha_{1}+\beta_{1} D_{f t}+\beta_{2} D_{2 t}+\beta_{3} D_{3 t}+\beta_{4} D_{4 t}+\beta_{5} D_{5 t}+\beta_{6} D_{J t}+\varepsilon_{t} \\
\varepsilon_{t} & \approx N\left(0, h_{t}\right)
\end{aligned}
$$

Table 3: Descriptive statistics of index futures contract trading (2017-2019)

\begin{tabular}{|l|c|c|c|}
\hline \multicolumn{1}{|c|}{ Indicators } & $\mathbf{2 0 1 7}$ & $\mathbf{2 0 1 8}$ & $\mathbf{2 0 1 9}$ \\
\hline Average daily trading volume (contract) & 10,954 & 79,335 & 88,186 \\
\hline Open interest (contract) & 451,274 & $3,321,236$ & $5,567,121$ \\
\hline Foreign investor trading volume (contract) & 8,493 & 32,336 & 203,808 \\
\hline The number of accounts & 17,374 & 57,677 & 92,202 \\
\hline Structure of investors & & & \\
\hline Domestic individuals (\%) & 99.0 & 95.0 & 85.8 \\
\hline Domestic institutions (\%) & 1.0 & 1.5 & 13.2 \\
\hline Foreign investors (\%) & 0.0 & 3.5 & 1.0 \\
\hline
\end{tabular}

Source: Own calculation by authors based on data collected from Ha Noi Stock Exchange Note: All figures are collected at the end of each year. 
where, $\mathrm{R}_{\mathrm{t}}$ is spot market returns (VN30-Index) at day $\mathrm{t}$; $\mathrm{D}_{\mathrm{ft}}$ is dummy variable for index future introduction, equal 1 if observation $t$ falls in the period from August 10 $0^{\text {th }}, 2017$ to December, 31st 2019 (post-index futures introduction period) and 0 otherwise (pre-index futures introduction period); $\mathrm{D}_{2}, \mathrm{D}_{3}, \mathrm{D}_{4}, \mathrm{D}_{5}, \mathrm{D}_{\mathrm{J}}$ are dummy variables for Monday, Tuesday, Thursday, Friday and January, respectively (these variables are used to control for the-day-of-the week and January effect that can be present in HOSE); $\varepsilon$ is an error term and assumed to be standard distribution.

The OLS model is based on the assumption of homocesdaticity, but it is usually violated in the context of financial time series. Moreover, according to Brooks (2002), if the assumption is not satisfied and the OLS model is still applied, the standard errors could be wrong and thus any inferences derived from the model could be not correct. To overcome this issue, the $\operatorname{GARCH}(1,1)$ model (Engle, 1982; Bollerslev, 1986) is employed in this study if ARCH (autoregressive conditional heteroscedasticity) effect is existence in the model. Specifically, the GARCH(1,1) takes the following form:

$$
\begin{aligned}
R_{t}= & \alpha_{1}+\beta_{1} D_{f t}+\beta_{2} D_{2 t}+\beta_{3} D_{3 t}+\beta_{4} D_{4 t} \\
& +\beta_{5} D_{5 t}+\beta_{6} D_{J t}+\varepsilon_{t} \\
\varepsilon_{t} \approx & N\left(0, h_{t}\right) \\
h_{t}= & \omega_{1}+\beta h_{t-1}+\alpha \varepsilon_{t-1}^{2}
\end{aligned}
$$

It is noted that the standard GARCH models assume that time-varying conditional volatility is symmetric. However, the impact of news on the volatility of stock prices is usually asymmetric. Specifically, bad news results in volatility of stock prices more than the good news (Kim, Kim \& Kim, 2004; Spyrou, 2005; Sahadudheen, 2015; Nguyen \& Nguyen, 2019). To deal with this issue, Nelson (1991) proposed the EGARCH (exponential generalized autoregressive conditional heteroskedasticity) model that captures the leverage effects in a time series. This study uses the $\operatorname{EGARCH}(1,1)$ model as a robustness check for the impact of index future introduction on the spot market returns in HOSE. The conditional variance of $\operatorname{EGARCH}(1,1)$ is taken by the following form:

$$
\ln \left(\sigma_{t}^{2}\right)=\omega_{1}+\beta \ln \left(\sigma_{t-1}^{2}\right)+\gamma \frac{\varepsilon_{t-1}}{\sqrt{\sigma_{t-1}^{2}}}+\alpha\left[\frac{\left|\varepsilon_{t-1}\right|}{\sqrt{\sigma_{t-1}^{2}}}-\sqrt{\frac{2}{\pi}}\right]
$$

In addition, to measure the impact of index futures introduction on the market trading volume, this study employs the OLS with the following form:

$$
\log \mathrm{VOL}_{t}=\alpha_{2}+\beta_{7} D_{f t}+\varepsilon_{t} \quad \varepsilon_{t} \approx N\left(0, h_{t}\right)
$$

where $\log \mathrm{VOL}_{\mathrm{t}}$ is the natural logarithm of trading shares at day $\mathrm{t} ; \mathrm{D}_{\mathrm{ft}}$ is dummy variable for index future introduction as defined above.

Then, the $\operatorname{GARCH}(1,1)$ is also employed to measure the impact of index future introduction on market trading volume as follow:

$$
\begin{aligned}
& \log \operatorname{VOL}_{t}=\alpha_{2}+\beta_{7} D_{f t}+\varepsilon_{t} \varepsilon_{t} \approx N\left(0, h_{t}\right) \\
& h_{t}=\omega_{2}+\varphi h_{t-1}+\lambda \varepsilon_{t-1}^{2}
\end{aligned}
$$

Finally, this study investigates the causal relationship between the spot market returns and future trading activity (volume) by using the Granger causality test that has widely used in the literature (Pok \& Poshakwale, 2004; Lee \& Zhao, 2014; Lee \& Brahmasrene, 2019). Following Garcia, Leuthold and Zapata (1986), the future trading activity (VOI) is measured by the ratio of future contracts trading volume (V) on open interests (OI). Specifically, the Granger causality tests is expressed as the following equations:

$$
\begin{aligned}
& R_{t}=\alpha_{0}+\sum_{l=1}^{k} \chi_{l} R_{t-l}+\sum_{l=1}^{k} \delta_{l} V O I_{t-l}+\varepsilon_{t} \\
& V O I_{t}=\alpha_{1}+\sum_{l=1}^{k} \phi_{l} V O I_{t-l}+\sum_{l=1}^{k} \rho_{l} R_{t-l}+v_{t}
\end{aligned}
$$

It is expected that both $\delta_{l}$ and $\rho_{l}$ coefficients are significantly difference from zero. In this case, it is concluded that bi-directional feedback exists between the spot market returns and future trading volume.

\section{Empirical Results}

\subsection{The Impact of Index Futures Trading on Spot Market Returns}

To test for the impact of index futures trading on spot market returns, OLS, $\operatorname{GARCH}(1,1)$ and $\operatorname{EGARCH}(1,1)$ regression models were used in this study. Estimated results derived from the models are presented in Table 4. First, the results of the OLS model show that the introduction of index futures contract in Vietnam has statistically insignificant impact on the spot market returns. However, this conclusion is based on the OLS model, which ignores the heteroscedasticity phenomenon (ARCH effect) that could be present in the model. To check for the presence of $\mathrm{ARCH}$ effect, the Lagrange Multiplier (LM) test, proposed by Engel (1982), is conducted, using 1 lag. The result of ARCH-LM test indicates that $\mathrm{ARCH}$ effect is presence in the model at the one percent level of significance. Therefore, the results 
of the OLS model could be wrong and thus any conclusions drawn from this model could be misleading. To deal with the limited OLS model, the GARCH $(1,1)$ and $\operatorname{EGARCH}(1,1)$ models are applied in the following step.

The empirical results drawn from the $\operatorname{GARCH}(1,1)$ and EGARCH(1,1) models consistently confirm that the introduction of index future contract has no impact on spot market returns. These results are contrary to the findings of Detemple and Jorion (1990) and Watt, Yadav, and Draper (1992) that indicate the positive impact of index future introduction on the returns of spot market. It is important to note that the index future contracts have traded in Vietnam for only about 2 years and the future trading volume has been rather low. Therefore, it could not be mature enough to impact on the spot market returns. In order to further investigate the impact of index future trading on the spot market returns, the Ganger causality test is also applied and the results derived from the test are presented in sub-section 5.3.
In addition, the results of the $\operatorname{EGARCH}(1,1)$ model indicate that the leverage effect on the spot market volatility is existence in HOSE (see Table 4). Specifically, the coefficient of leverage effect is negative $(-0.0407)$ and statistically significant at the one percent significant level. Therefore, it can be concluded that bad news has a greater effect on the market volatility than good news of the same magnitude.

\subsection{The Impact of Index Future Introduction on Market Trading Volume}

The results of the impact of index future introduction on the spot market trading volume are presented in Table 5. Firstly, the results derived from the OLS model show that the introduction of index future contract has significant effect on the spot market trading volume. Specifically, the average of daily market trading volume in the post-index futures

Table 4: Summarized results of OLS, GARCH $(1,1)$ and $\operatorname{EGARCH}(1,1)$ models

\begin{tabular}{|c|c|c|c|}
\hline Variable & OLS & GARCH $(1,1)$ & $\operatorname{EGARCH}(1,1)$ \\
\hline \multicolumn{4}{|c|}{ Conditional mean equation } \\
\hline$\alpha_{1}$ & $\begin{array}{c}0.000540 \\
(2.25)^{* *}\end{array}$ & $\begin{array}{c}0.000495 \\
(2.34)^{* *}\end{array}$ & $\begin{array}{c}0.000443 \\
(2.11)^{* *}\end{array}$ \\
\hline$\beta_{1}$ & $\begin{array}{c}-0.000035 \\
(-0.16)\end{array}$ & $\begin{array}{c}0.000072 \\
(0.39)\end{array}$ & $\begin{array}{c}0.000034 \\
(0.20)\end{array}$ \\
\hline$\beta_{2}$ & $\begin{array}{c}-0.000676 \\
(-2.07)^{* *}\end{array}$ & $\begin{array}{c}-0.000607 \\
(-2.32)^{* *}\end{array}$ & $\begin{array}{c}-0.000526 \\
(1.96)^{* *}\end{array}$ \\
\hline$\beta_{3}$ & $\begin{array}{c}-0.000639 \\
(-1.97)^{* *}\end{array}$ & $\begin{array}{c}-0.000438 \\
(-1.59)\end{array}$ & $\begin{array}{c}-0.000340 \\
(-1.27)\end{array}$ \\
\hline$\beta_{4}$ & $\begin{array}{c}-0.000838 \\
(-2.60)^{*}\end{array}$ & $\begin{array}{c}-0.000495 \\
(-1.80)^{* * *}\end{array}$ & $\begin{array}{c}-0.000422 \\
(-1.54)\end{array}$ \\
\hline$\beta_{5}$ & $\begin{array}{c}0.000087 \\
(0.27)\end{array}$ & $\begin{array}{c}-0.000037 \\
(-0.13)\end{array}$ & $\begin{array}{c}-0.000075 \\
(-0.27)\end{array}$ \\
\hline$\beta_{6}$ & $\begin{array}{c}0.000412 \\
(1.42)\end{array}$ & $\begin{array}{c}0.000356 \\
(1.85)^{*+*}\end{array}$ & $\begin{array}{c}0.000473 \\
(2.33)^{* *}\end{array}$ \\
\hline ARCH-LM test (1 lag) & $52.35^{*}$ & & \\
\hline \multicolumn{4}{|c|}{ Conditional variance equation } \\
\hline$\omega_{1}$ & & $\begin{array}{c}6.67 \mathrm{E}-07 \\
(5.18)^{*}\end{array}$ & $\begin{array}{c}-0.643135 \\
(-7.00)^{*}\end{array}$ \\
\hline$\alpha(\mathrm{ARCH}$ effect $)$ & & $\begin{array}{c}0.100131 \\
(8.46)^{*}\end{array}$ & $\begin{array}{c}0.214845 \\
(9.98)^{*}\end{array}$ \\
\hline$\beta$ (GARCH effect) & & $\begin{array}{c}0.868649 \\
(61.48)^{*}\end{array}$ & $\begin{array}{l}0.956345 \\
(123.84)^{*}\end{array}$ \\
\hline$\gamma$ (leverage effect) & & & $\begin{array}{c}-0.040700 \\
(-4.25)^{*}\end{array}$ \\
\hline
\end{tabular}

$*, * *, * * *:$ significant at the $1 \%, 5 \%$ and $10 \%$ levels respectively.

t-values in parentheses for OLS model and z-values in parentheses for $\operatorname{GARCH}(1,1)$ and EGARCH models 
introduction period is higher than the pre-index futures introduction period at the significantly statistical level of one percent. It is noted that the results of ARCH-LM test strongly indicate that ARCH effect is existence in the OLS model. Therefore, GARCH $(1,1)$ is applied in the next step. Similar to the OLS model, the findings from $\operatorname{GARCH}(1,1)$ model also reveal that the index future introduction is associated with the increase in market trading volume in HOSE at the level of one percent statistically. Based on these findings, it can be concluded that the introduction of index future contract has a positive effect on the trading volume of HOSE.

\subsection{Causal Relationship between the Spot Market Returns and Future Trading Activity}

It is noted that the Granger causality requires both studied series to be stationary. Therefore, the unit root test should be conducted as a pre-test in order to determine the level of integration of the observed series. The results of the ADF presented in Table 6 indicate that the null hypothesis of a unit root is significantly rejected for both the daily market returns and VOI series in level because the t-statistic is larger than their corresponding critical value (MacKinnon's critical value). In the other words, it is concluded that both the daily market returns and VOI series are stationary or integrated to the order zero.

In order to determine the appropriate lag length for the observed series in the Granger causality model, the optimal lag length (k) is selected by using the AIC technique with 12 lags to be included. As a result, the optimal lag length to be found for the model is eight. Based on the results of the
ADF and AIC tests, the Granger causality test is conducted and the results are reported in Table 7 . As can be seen in Table 7, the null hypothesis that the spot market returns (R) do not Granger cause future trading activity (VOI) is significantly rejected at the one percent level. The rejection of the null hypothesis indicates that the spot market returns is viewed as valuable information to forecast the future trading activity. In the opposite direction, the results reveal that the spot market returns are not significantly caused by the future trading activity. This finding confirms again that the index future trading does not impact on the spot market returns. Based on these findings, it is concluded that the unidirectional causality running from the market returns to the future trading activity is presence in HOSE.

\section{Conclusion}

This study investigates the impact of index futures introduction on spot market returns and market trading volume for the case of HOSE by using the daily series market returns and trading volume of HOSE during the period from February $6^{\text {th }}, 2012$ to December $31^{\text {st }}, 2019$. The empirical results drawn from $\operatorname{GARCH}(1,1)$ and $\mathrm{EGARCH}(1,1)$ models reveal that the introduction of index future contracts has no impact on the spot market returns. In addition, the results derived from the Granger causality test for the relationship between the spot market returns and the future trading activity confirm that the unidirectional causality running from the market returns to the future trading activity is existence in HOSE. Moreover, it is found that the introduction of index future contracts has positive effects on spot market trading

Table 5: The impact of index futures trading on market trading volume

\begin{tabular}{|c|c|c|}
\hline Variable & OLS & $\operatorname{GARCH}(1,1)$ \\
\hline \multicolumn{3}{|c|}{ Conditional mean equation } \\
\hline$\alpha_{2}$ & $\begin{array}{c}7.495523 \\
(1,213.04)^{*}\end{array}$ & $\begin{array}{c}7.619480 \\
(1,641.01)^{*}\end{array}$ \\
\hline$\beta_{7}$ & $\begin{array}{c}0.210911 \\
(18.81)^{*}\end{array}$ & $\begin{array}{c}0.074880 \\
(9.99)^{*}\end{array}$ \\
\hline $\begin{array}{l}\text { ARCH-LM test } \\
(1 \mathrm{lag})\end{array}$ & $1,803.88^{*}$ & \\
\hline \multicolumn{3}{|c|}{ Conditional variance equation } \\
\hline$\omega_{2}$ & & $\begin{array}{c}0.002695 \\
(6.04)^{*}\end{array}$ \\
\hline$\phi$ & & $\begin{array}{c}0.338554 \\
(7.14)^{*}\end{array}$ \\
\hline$\lambda$ & & $\begin{array}{c}0.594751 \\
(12.80)^{*}\end{array}$ \\
\hline
\end{tabular}

*: significant at the $1 \%$ level.

t-values in parentheses for OLS model and z-values in parentheses for GARCH $(1,1)$ model 
Table 6: ADF unit root test results for the selected series

\begin{tabular}{|l|c|c|c|}
\hline \multicolumn{1}{|c|}{ Variables } & Lag length & Constant without trend & Constant with trend \\
\hline The daily market returns (R) & 1 & $-15.58^{*}$ & $-15.76^{*}$ \\
\hline Future trading volime (VOI) & 4 & $-3.48^{*}$ & $-3.46^{*}$ \\
\hline
\end{tabular}

": Significant at the $1 \%$ level.

Table 7: Results of the Granger causality test

\begin{tabular}{|l|c|c|c|}
\hline Null hypothesis & F-statistic & Lag length & Decision \\
\hline R does not Granger cause VOI. & $6.32^{*}$ & 8 & Reject \\
\hline VOI does not Granger cause R. & 1.47 & 8 & Accept \\
\hline
\end{tabular}

*: Significant at the $1 \%$ level.

volume. Specifically, the spot market trading volume of the post-index futures introduction increase by 7.5 percent compared with the pre-index futures introduction. This finding implies that the introduction of index future contracts has provided useful facilities for speculation and hedge that have met the need of investors. The results also confirm that the initial objectives of the Vietnamese government when launching the index future contract have been fulfilled. Therefore, the government should expand futures contracts on individual stocks in the near future.

\section{References}

Aitken, M., \& Segara, R. (2005). Impact of warrant introductions on the behaviour of underlying stocks: Australian evidence. Accounting and Finance, 45(1), 127-144.

Antoniou, A., \& Holmes, P. (1995). Futures trading, information and spot price volatility: Evidence for the FTSE-100 stock index futures contract using GARCH. Journal of Banking and Finance, 19, 117-129.

Bae, S. C., Kwon, T. H., \& Park, J. W. (2004). Futures trading, spot market volatility, and market efficiency: The case of the Korean index futures markets. Journal of Futures Markets, 24(12), 1195-1228.

Bollerslev, T. (1986). Generalized autoregressive conditional heteroskedasticity. Journal of Econometrics, 31(3), 307-327.

Bologna, P., \& Cavallo, L. (2002). Does the introduction of index futures effectively reduce stock market volatility? Is the futures effect immediate? Evidence from the Italian Stock Exchange using GARCH. Applied Financial Economics, 12(3), 183-92.

Brooks, C. (2002). Introductory Econometrics for Finance. Cambridge, UK: Cambridge University Press.

Detemple, J., \& Jorion, P. (1990). Option listing and stock returns: An empirical analysis. Journal of Banking and Finance, 14, 781-801.
Engle, R. F. (1982). Autoregressive conditional heteroscedasticity with estimates of the variance of United Kingdom inflation. Econometric, 50(4), 987-1007.

Garcia, P., Leuthold, R. M., \& Zapata, H. (1986). Lead-lag relationship between trading volume and price variability: new evidence, Journal of Futures Markets, 6, 1-10.

Faff, R. W., \& McKenzie, M. D. (2002). The impact of stock index futures trading on daily returns seasonality: A multicountry study. Journal of Business, 75(1), 95-125.

Garcia, P., Leuthold, R. M., \& Zapata, H. (1986). Lead-lag relationship between trading volume and price variability: new evidence, Journal of Futures Markets, 6, 1-10.

Gulen, H., \& Mayhew, S. (2000). Stock index futures trading and volatility in international equity markets. Journal of Futures Markets: Futures, Options, and Other Derivative Products, 20 , 661-685.

Hou, Y., \& Li, S. (2014). The impact of the CSI 300 stock index futures: Positive feedback trading and autocorrelation of stock returns. International Review of Economics \& Finance, 33, 319-337.

Kim, M., Kim, G. R., \& Kim, M. (2004). Stock market volatility and trading activities in the KOSPI 200 derivative markets. Applied Economics Letter, 11(1), 49-53.

Lee, C. I., \& Tong, H. C. (1998). Stock futures: the effects of their trading on the underlying stocks in Australia. Journal of Multinational Financial Management, 8, 285-301.

Lee, J. W., \& Brahmasrene, T. (2019). Long-run and shortrun causality from exchange rates to the Korea composite stock price index. Journal of Asian Finance, Economics and Business, 6(2), 257-267. https://doi.org/10.13106/jafeb.2019. vol6.no2.25.

Lee, J. W., \& Zhao, T. F. (2014). Dynamic relationship between stock prices and exchange rates: Evidence from Chinese stock markets. Journal of Asian Finance, Economics and Business, 1(1), 5-14. https://doi.org/10.13106/jafeb.2014.vol1.no1.5. 
Lee, S. B., \& Ohk, K. Y. (1992). Stock index futures listing and structural change in time-varying volatility. Journal of Futures Markets, 12(5), 493-509.

McKenzie, M. D., Brailsford, T. J., \& Faff, R. W. (2001). New insights into the impact of the introduction of futures trading on stock price volatility. Journal of Futures Markets, 21(3), 237-255.

Nelson, D. B. (1991). Conditional heteroskedasticity in asset returns: A new approach. Econometrica, 59(2), 347-370.

Nguyen, C. T., \& Nguyen, M. H. (2019). Modeling stock price volatility: Empirical evidence from the Ho Chi Minh City Stock Exchange in Vietnam. Journal of Asian Finance, Economics and Business, 6(3), 19-26. https://doi.org/10.13106/jafeb.2019. vol6.no3.19.

Park, H. Y., \& Park, S. Y. (2020). Does hedging with derivatives affect future crash risk?. Journal of Asian Finance, Economics and Business, 7(4), 51-58. https://doi.org/10.13106/jafeb.2020. vol7.no4.51.

Pilar, C., \& Rafael, S. (2012). Does derivatives trading destabilize the underlying Assets? Evidence from the Spanish stock market. Applied Economics Letters, 2(5), 113-126.

Pok, W. C., \& Poshakwale, S. (2004). The impact of the introduction of futures contracts on the spot market volatility: The case of Kuala Lumpur Stock Exchange. Applied Financial Economics, 14(2), 143-154.

Robbani, M. G., \& Bhuyan, R. (2005). Introduction of futures and options on a stock index and their impact on the trading volume and volatility: Empirical evidence from the DJIA components. Derivatives Use, Trading and Regulation, 11(3), 246-260.

Sahadudheen, I. (2015). An exponential GARCH approach to the effect of impulsiveness of Euro on Indian stock market. Journal of Asian Finance, Economics and Business, 2(3), 17-22. https:// doi.org/10.13106/jafeb.2015.vol2.no3.17.

Spyrou, S. I. (2005). Index futures trading and spot price volatility: Evidence from an emerging market. Journal of Emerging Market Finance, 4(2), 151-167.

Tripathy, N., Ramana Rao, S. V., \& Kanagaraj, A. (2009). Impact of derivatives trading on spot market volatility: an empirical study. International Journal of Applied Decision Sciences, 2(2), 209-232.

Truong, D. L., Lanjouw, G. \& Lensink, R. (2006). The impact of privatization on firm performance in a transition economy: The case of Vietnam. Economics of Transition, 14(2), 349-389.

Watt, W. H., Yadav, P. K., \& Draper, P. (1992). The impact of option listing on underlying stock returns: The UK evidence. Journal of Business Finance \& Accounting, 19(4), 485-503.

Yilgor, A. G., \& Mebounou, C. L. C. (2016). The effect of futures contracts on the stock market volatility: An application on Istanbul stock exchange. Journal of Business, Economics and Finance, 5(3), 307-317.

$\mathrm{Yu}, \mathrm{S}$. W. (2001). Index futures trading and spot price volatility. Applied Economics Letters, 8(3), 183-186. 